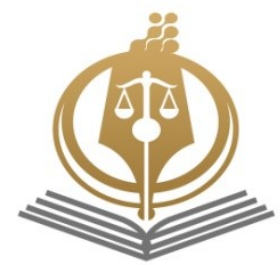

Interdisciplinary Legal Research

Apr 2020, 1(1): 39-54

Available online on: www. ilrjournal.ir

e-ISSN:2717-1795

ORIGINAL RESEARCH PAPER

\title{
Medical and Legal Justifications for Decriminalization of Soft Drugs
}

Seyed Reza Ehsanpour ${ }^{1 *}, \quad$ Mohammad Ali Mahdavi Sabet ${ }^{2}$

Received:

22 Mar 2020

Revised:

26 Mar 2020

Accepted:

28 Mar 2020

Available Online:

01 Apr 2020

Keywords:

Soft drugs,

Criminalization,

Decriminalization,

Medical Justification,

Crime.

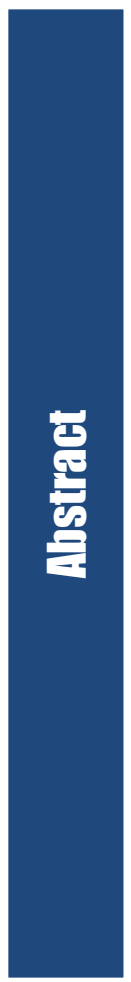

Background and Aim: Soft drugs are a relatively new concept that has no history at least in our country's legal and social literature. The term is referred to as a form of drugs with specific features and refers to those substances whose consumption is not likely to cause addiction, has less adverse effects on the health of the body and can be expected to use it as a treatment

Materials and Methods: This syudy id of descriptive - analytical one.

Ethical Considerations: Authenticity of the texts, honesty and confidentiality have been observed in this study.

Findings: The characteristics have caused some tendency to decriminalization of this type of drugs. However, the opposition believes that the decriminalization is in the first place opposed to legal moralism and secondly because it violates international obligations of governments. Also, releasing these drugs, such as hashish, will reduce prices and eventually increase its consumption. In addition to the implication of a large number of studies, Decriminalization of soft drugs consumption amounts to an increase in crimes especially financial crimes. The experience of countries already involved in drug abuse has also been an unsuccessful experience.

Conclusion: Decriminalization of soft drugs, in spite of some benefits, opposes many legal instruments and medical finds.

1* Assistant Professor, University of Shahed, Tehran, Iran. (Corresponding Author)

Email: Ehssanpour@Shahed.ac.ir Phone: +989373412963

2 Assistant Professor, Department of Criminal Law, University of Imam Sadiq, Tehran, Iran.

Please Cite This Article As: Ehsanpour, SR \& Mahdavi Sabet, MA (2020). "Medical and legal Justifications for Decriminalization of Soft Drugs". Interdisciplinary Legal Research, 1 (1): 39-54. 


\section{توجيهات حقوقى - يزشكى مخالف با جرمزدايى از مصرف مصرف مواد مخدر آرام}

\section{سيد رضا احسانيور '، محمدعلى مهدوى ثابت ‘}

Email: Ehssanpour@Shahed ac.ir (استاديار، گروه حقوق، دانشگاه شاهد، تهران، ايران. (نويسنده مسؤول)

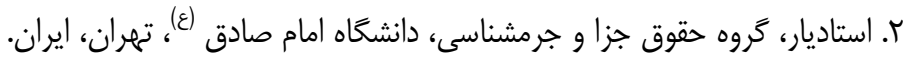

دريافت:

زمينه و هدف: مواد مخدر آرام مفهوم نسبتاً جديدى است كه لااقل در ادبيات حقوقى و اجتماعى كشور ما داراى سابقه نيست. اين اصطلاح به عنوان

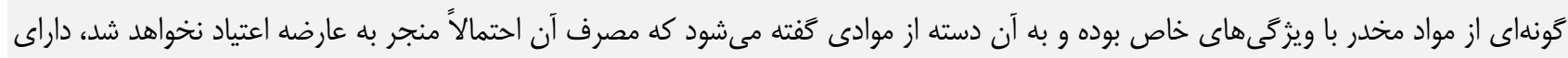
آثار سوء كمترى بر سلامت بلدن است و مىتوان امكان استفاده درمانى از ان مان را انتظار داشت. مواد و روشها: روش تحقيق در اين يزوهش به صورت توصيفى -تحليلى است.

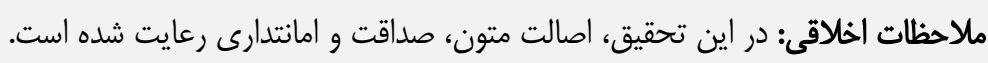

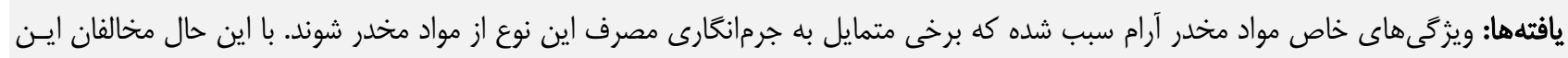

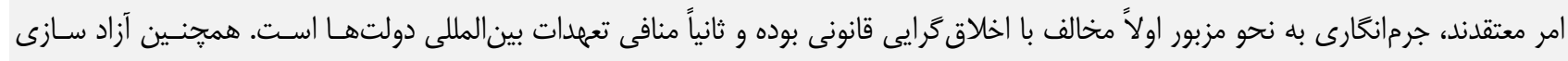

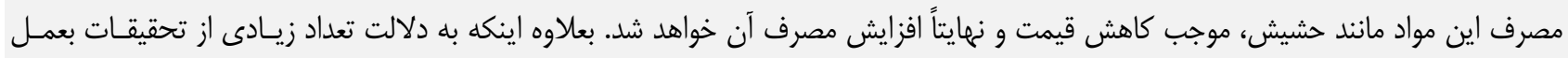

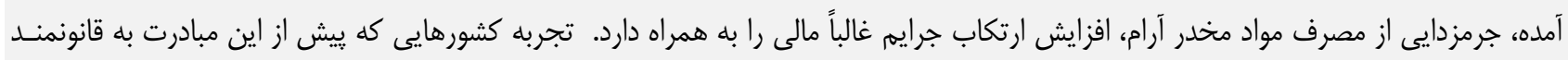
كردن مصرف اين مواد نمودهاند نيز تجربهاى ناموفق بوده است.

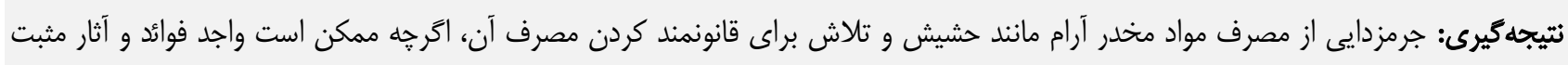

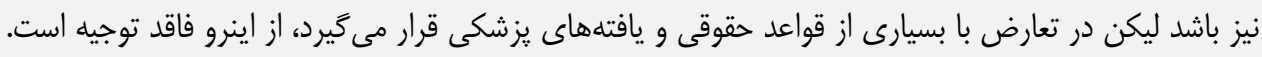

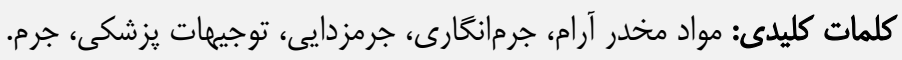


(FreeDictionary.com, 2020) متحده، مفهوم ماده مخدر آرام قابل صدق بر "حشيش" است. r- روش تحقيق: روش تحقيق در اين يزوهش بلهورت تحليلى و توصيفى است.

بحث و نظر عمده توجيهات حقوقى در مخالفت با قانونمند سازى و جرمزدايى از مصرف مواد مخدر آرام (از جمله حشيش) به شرح ذيل است:

\section{1- اخلاقكرايى حقوقى}

يكى از دلايل مخالفت با جرمزدايى مصرف مواد مخدر آرام

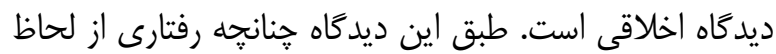

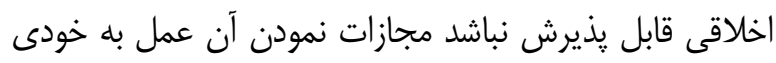

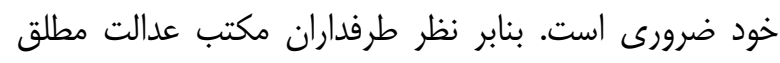

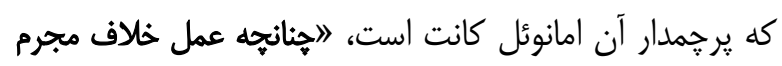
به خود وى بازكشته باشد، وى نمى تواند مدعى بى عدالتى عليه خود

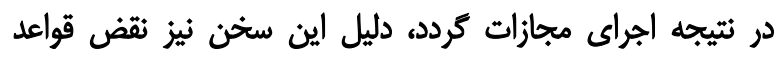
اخلاقى توسط مجرم در نتيجه ارتكاب جرم مىباشد." (اردبيلى،

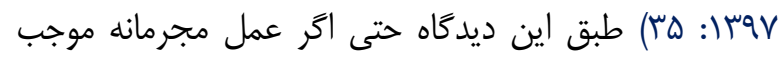
آثار منفى بر ساير افراد جامعه نيز نخردد، اما به دليل نقض قواعد اخلاقى، مرتكب، مستحق اعمال مجازات خواهد بود. از

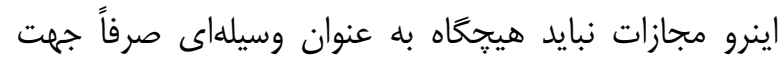

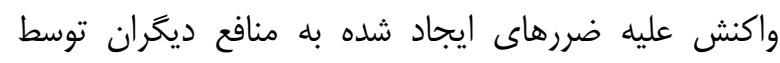

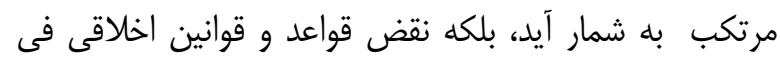
نفسه مستحق مجازات مىباشد. اين ديدكاه در قرن بيسته نيز

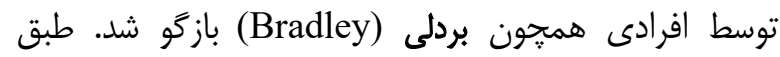
عبارت مشهور وى، لاما مجازات را مىيذيريم جون لايق و روني

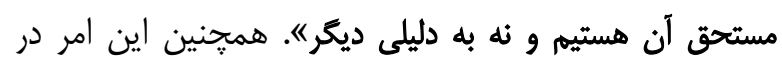
فرهنگ كليساى كاتوليك نيز بخوبى نمايان است. كليسا

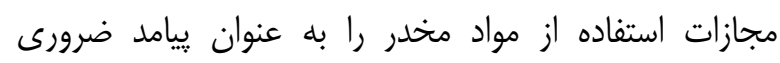
بداخلاقى در مصرف مواد مخدر مىداند. عقيده اصلى كليساى

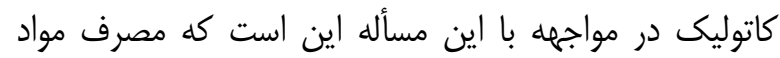

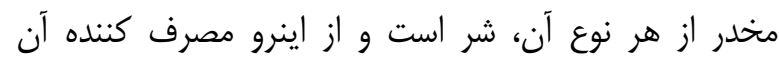

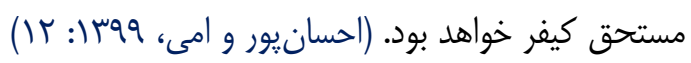

\section{مقدمه} 1- بيان موضوع: اتخاد سياستهاى نوين در مبارزه با مصـرف

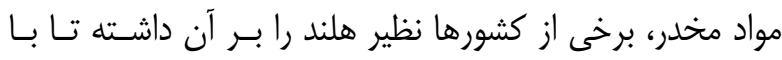
تميز ميان انواع مواد مخدر، مصرف كونـهـهـاى كمه خطـر تـر،

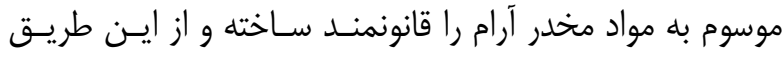

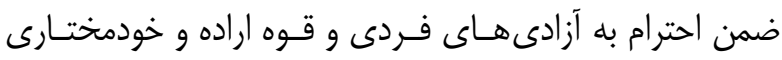

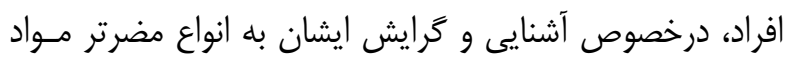
مخدر ييشخيرى نموده و نيز مصـرف مـواد مخـدر در كشـور را

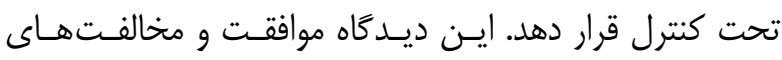
بسيارى را در حوزه مباحث حقوقى و يزشكى بـه همــراه داشـته

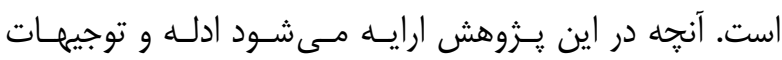

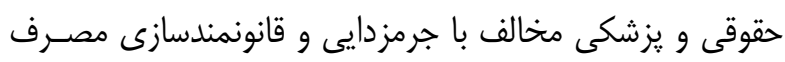
مواد مخدر آرام است.

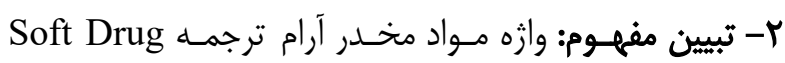

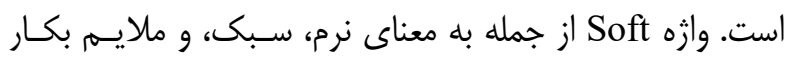

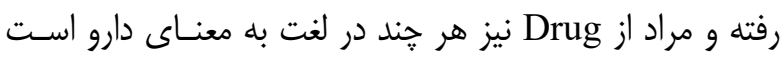
لكن اغلب در مفهوم داروهاى غيرقانونى، غيرمجـاز و ســرانجام مواد مخدر بكار مىرود. (OxfordDictionary.com, 2020) از كنار هم قرار گَرفتن اين دو وازثه، تركيب وصفى مــواد مخــدر

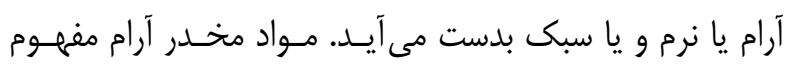

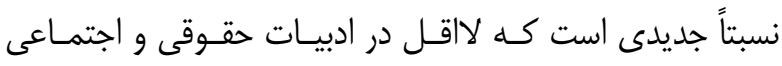
كشور ما داراى سابقه نيست. اين اصطلاح به عنوان گونـهاى از از

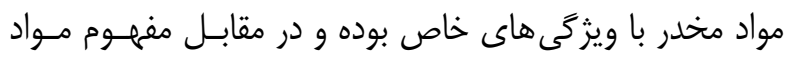
مخدر سخت قرار مى گيرد.

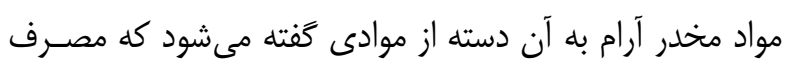

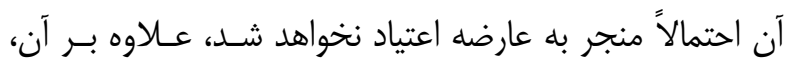

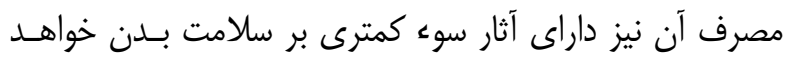

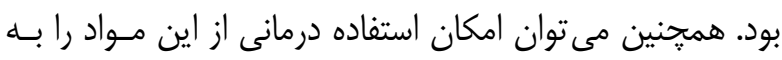
عنوان ضابطه تمايز ديخرى با ديگر انواع مواد مخدر دانست. بنا

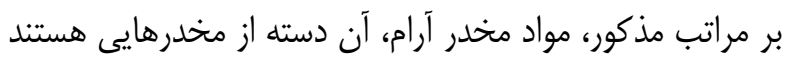

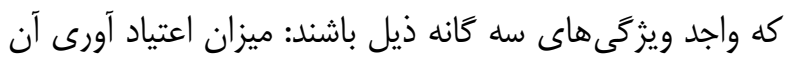

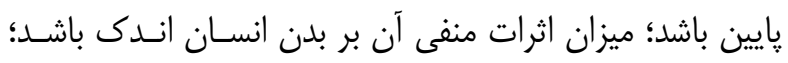

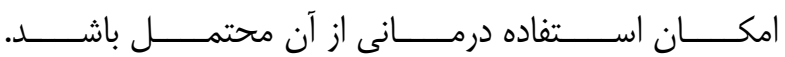


كرديد. در اين مكان معتادان بدون هيج واهمهاى به خريد و فروش و مصرف مواد مخدر يرداخته و پيليس نيز هيج نوع بن

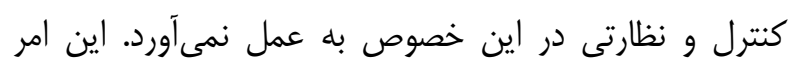

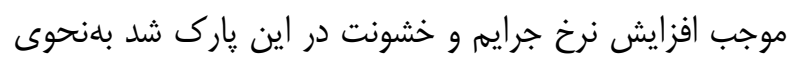
كه در نهايت مسؤولان اقدام به تعطيلى اين بارك در در سال

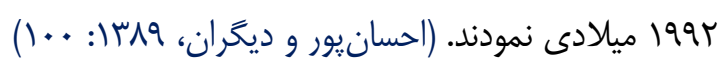

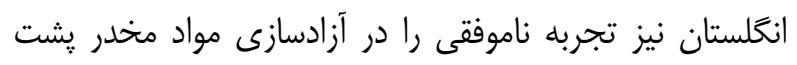

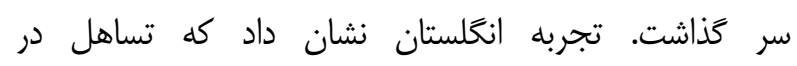
سياستهاى مربوط به مواد مخدر منجر به افزايش مصرف و لهربه افزايش تعداد معتادان خواهد شد. طبق سياست سمل گئيرانه

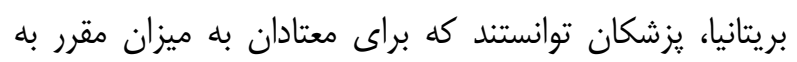

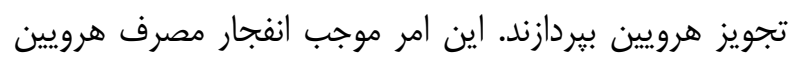

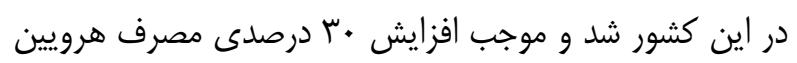

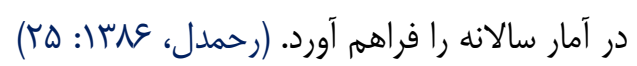

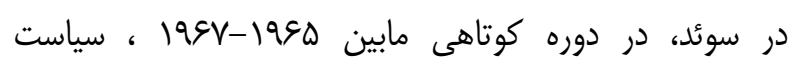
سهل گيرانهاى ييرامون مواد مخدر وجود داشت. در اين دوران

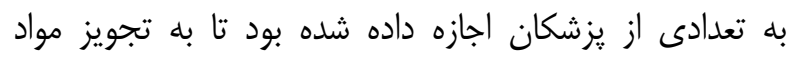

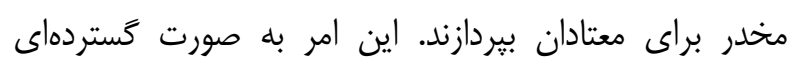

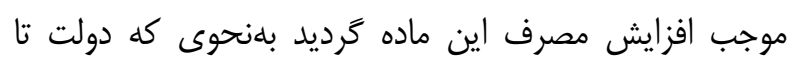

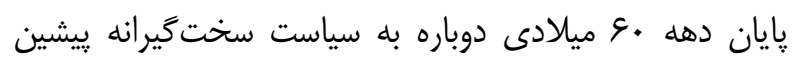

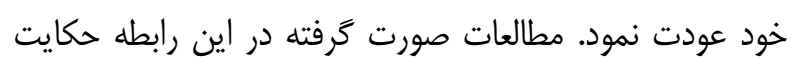

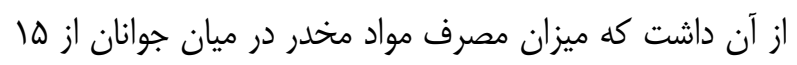

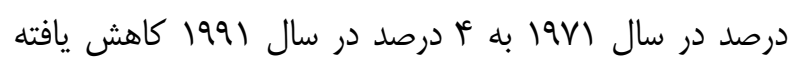

(Kaplin, 1994: 12) (ست)

\section{3- تاثير "قابليت دسترسى" و "اقيمته بر مصرف}

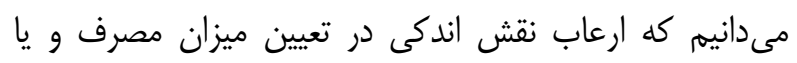

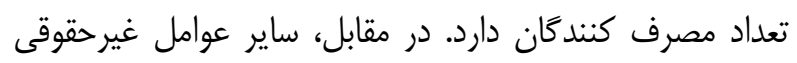
نظير ميزان دسترسى به مواد مخدر و قيمت، از عوامل تأثير تذار

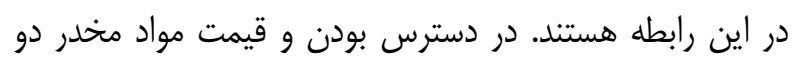
عامل مهم مصرف حشيش به شمار مىآيد. ( : Warner, 1991

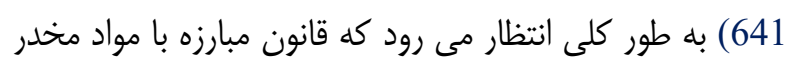
با جرمانغارى مصرف مواد، از طريق محدود كردن القابليت مونى دسترسى" به مواد مخدر موجب كاهش مصرف آن گردد. r- تجربه ناموفق جرمزدايى به زعم مخالفان، قانونمندى مصرف مواد مخدر آرام، در درو

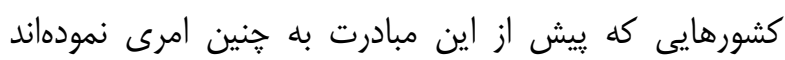

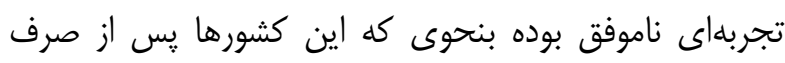

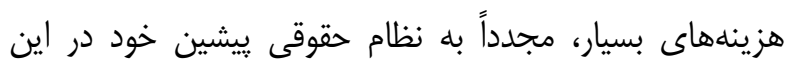

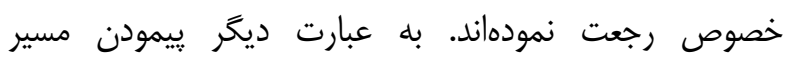
اشتباهى كه ديخران آنرا ييمودهاند عقلايى نيست.

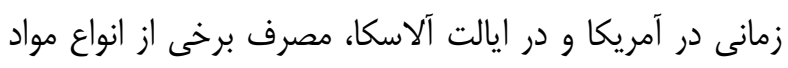

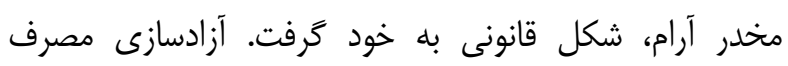
حشيش در دهd •V ميلادى، سبب شد كه جمعيت معتادان در

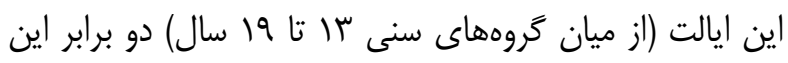
مقدار در ساير كشورها باشد. در نتيجه نيز افت تحصيلى ميلى

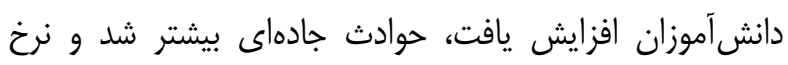

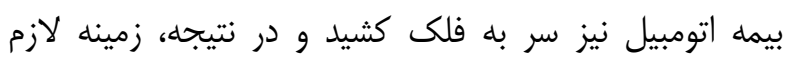
جهت جرمانغارى مجدد حشيش در • . 199 را فراهم آورد.

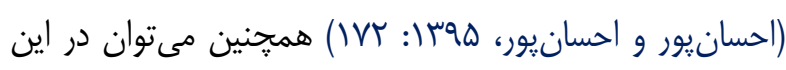
خصوص به سياست داروئى و مواد مخدر اسيانيا اشاره كرد. اين مئن كشور در سال 19v8، مصرف تمامى انواع مواد مخدر و و

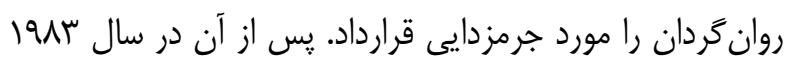
و در زمان حكومت سوسياليستى فيلييو كنزالس، براى نخستين

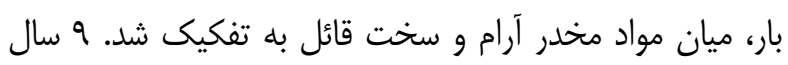

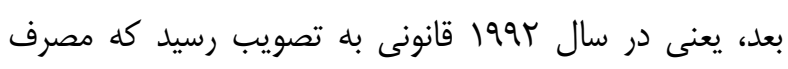

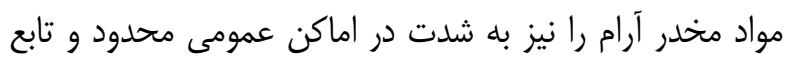

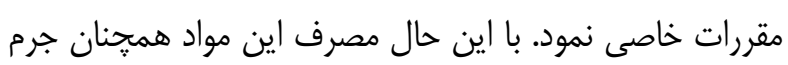

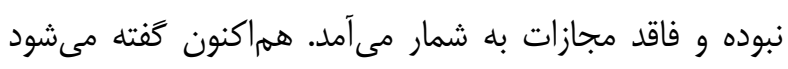

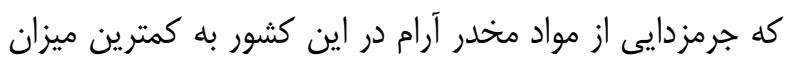

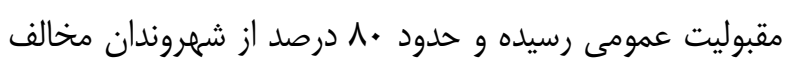

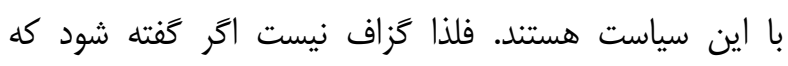
سياست سمل گيرانه اسبانيا در قبال مواد مخدر آرام، سياستى سئى شكست خورده است. (احسانيور و امى، و9 وسا: سا) كشور سوئيس كه به داشتن سياست دارويى ليبرال در ارويا مشهور است، اقدام به راه اندازى يارك تزريقات در اين كشور نمود. اين يارك به زودى كعبه آمال تمامى معتادان در ارويا 
خصوص تغيير در مصرف مواد و جرم در طول زمان نشان داده

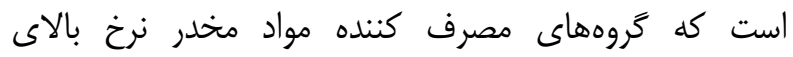
بزهكارى را ييش از مصرف مواد مخدر نيز به ثبت رسانده بودند. نيوكامب (Newcomb) و بنتلر (Bentter) از رابطه مثبت ميان مصرف مواد و ارتكاب بزهكارى سخن كَفتهاند. (Newcomb \& Bentler, 1988: 8) (White) مصرف حشيش و ارتكاب جرم در ايالات نيوجرسى در ميان

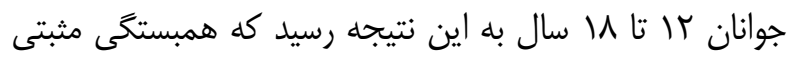
ميان مصرف حشيش و وقوع بزهكارى وجود دارد. (White,1991: 231) (Horwood) معيار توجه نشان دادند. معيارهاى مزبور عبارت بودند از جرايم

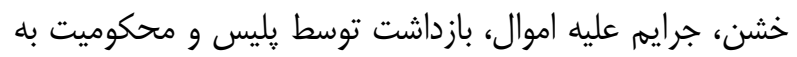

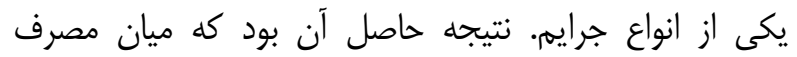
حشيش و وقوع بزهكارى از جانب نوجوانان زير عاسال رابطه مثبتى وجود دارد. (Fergusson \& Horwood, 1997: 279) نتائج حاصل از تحقيقات بروى (Brook) و همكاران وى نيز از رابطه مثبت ميان مصرف حشيش و افزايش دو برابرى احتمال وقوع جرايم خشونت آميز حكايت دارد. ) Brook \& et al,

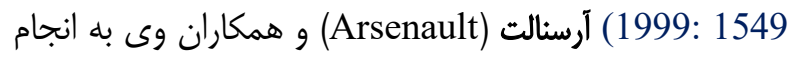
مطالعهاى درخصوص رابطه ميان ناهنجارىهاى روانى و بروز خشونت در ميان نمونه آمارى اعو نفره از نوجوانان نيوزلندى

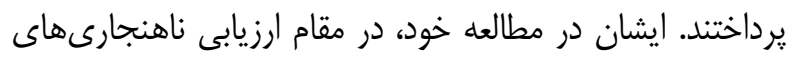
مزبور، به وابستخى افراد به مواد مخدر و شرب الكل توجه نشان داده و نقش آن در بروز خشونت را به مطالعه كذاردند. وقوع خشونت از دو طريق "خود اظهارى" توسط نمونههاى آمارى و و دون

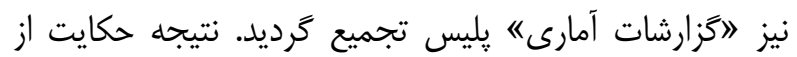

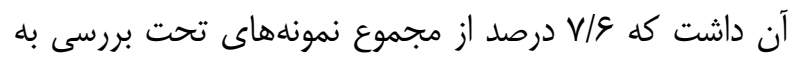

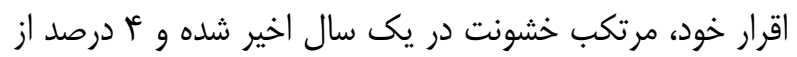

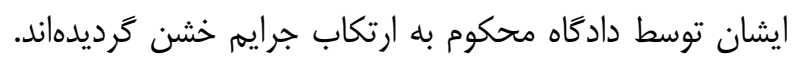
همجنين ايشان به بيوند قوى ميان وقوع خشونت در نتيجه
ديخر آنكه انتظار مى رود، كاهش قابليت دسترسى به مواد

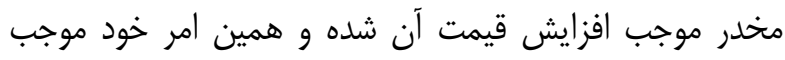
كاهش تمايل به مصرف آن كردد. ) Reuter \& Kleiman, (1989: 286 ץ- افزايش آمار ارتكاب جرايم

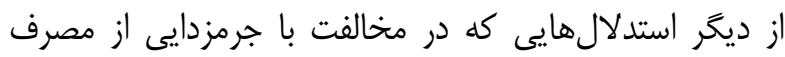
مواد مخدر آرام بيان مىشود آن است كه مصرف اين مواد آنهاد

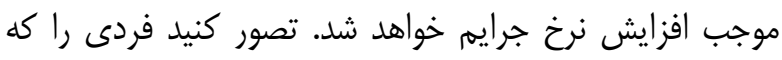
بدليل مصرف ماده مخدر نظير حشيش، درك خود را از دست

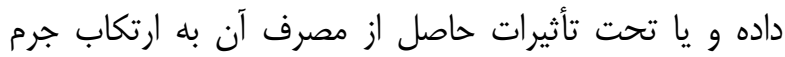
بيردازد. طيف جرايمى كه اين كروه مىتوانند مرتكب آن شود بسيار وسيع است و از تخلفات راهنمايى و رانندگى تا قتل در نوسان مىباشد. به عنوان مثال ممكن است فردى كه

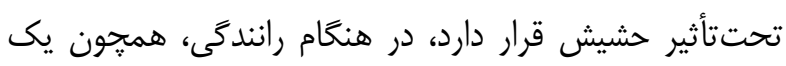
انسان مست، از كنترل اتومبيل تحت هدايت خود ناتوان شده و

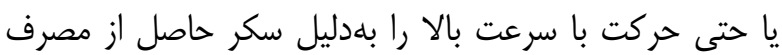
مخدرات، اندى تصور نمايد و در نتيجه منجر به حادثه رانندگى

كردد. (Donovan \& Jessor, 1983:543)

ץ-1- شواهد تحقيقاتى تحقيقات نشان داده است كه ميان ارتكاب جرايم، خشونت و مصرف مواد، رابطه مستقيم وجود دارد. مصرف حشيش و ساير انواع مواد مخدر با عدم سازگًارى اجتماعى نيز در ارتباط است. (Polich \& et al, 1984: 12) ميان مصرف حشيش و عمر بزهكارى در بين مصرفكنندكان

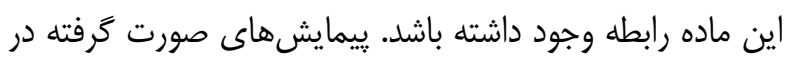
خصوص مصرف مواد در ميان جوانان، نشان از رابطه ميان Salmelainen, ) مصرف منظم حشيش و كثرت جرايم دارد. (1995: 15; Trimboli, 1998:12 به عنوان مثال جانسون و همكاران وى به بررسى رابطه ميان مصرف مواد (Johnston) و بزهكارى در ميان مردان يرداختند و به اين نتيجه رسيدند كه رفتارهاى مجرمانه با افزايش نرخ مصرف مواد در ارتباط است. (Johnston \& et al, 1978: 14) 
دسته دوم، جرايم توام با خشونت است كه فرد معتاد در نتيجه

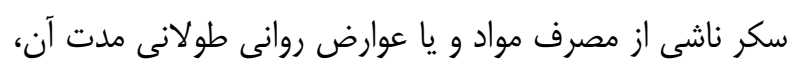
مرتكب رفتارهاى خشونت آميز مى گردد. بلهعنوان مثال كَفته

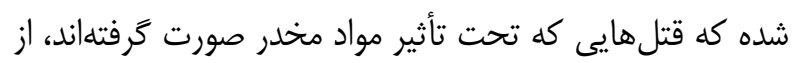
حيث فراوانى شش برابر بيش از ساير انواع قتلها است. آمار،

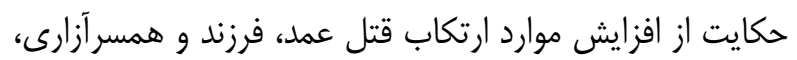
تخريب اموال ديخران، زنا، تهاجم و ساير انواع جرايم خشونتآميز تحت تأثير مصرف مواد مخدر و بطور خاص مصرف تهرف

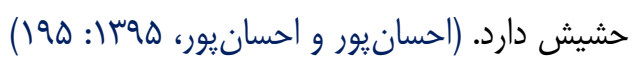

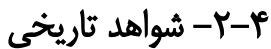

در آمريكا نخستين يبيوند ميان مصرف حشيش و اعمال خشونتآميز به تاريخ عبوا ميلادى در قالب مقالهاى علمى دئين برقرار گرديد. يس از آن ابتكار عمل در اين خصوص در اختيار اداره مواد مخدر فدرال قرار گرفت تا اين اداره در مقام تضمين بردين قانون مبارزه با حشيش در سال 19rr سلسله مطالعات سازمان

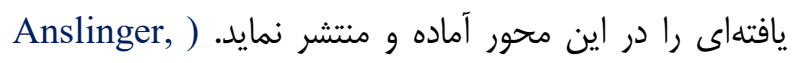
(1937: 156 جهت تاييد اظهارات رسمى اداره مواد مخدر فدرال، تلاشهاى بسيارى نيز صورت كرفت كه نخستين دليل اقامه شده بر خشونتآميز بودن مصرف حشيش، توجه به سابقه لهابه تاريخى اين امر و ريشه شناسى لغوى آن به شرح ذيل است.

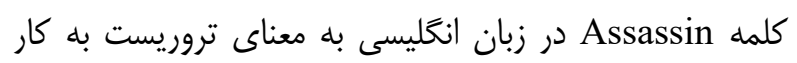
مىرود. اين لغت بركرفته از لفظ حشيش است. كفته شده كه حسن صباح از دُعات معروف اسماعيليه كه در قلعه مستحكم الموت در ايران اقامت داشته، قبل از اعزام نيروهاى خود جهت

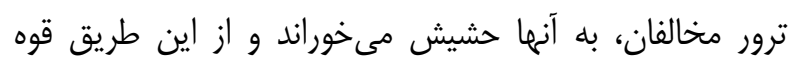

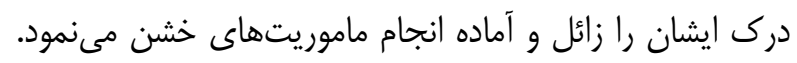

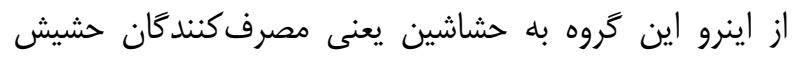
معروف شدند. اين لفظ بعدها به حسّاسين (Hassassin) و

سيس به Assassin تغيير يافت. (Fussier, 1931:84) البته در اين خصوص روايت ديگرى نيز وجود دارد. طبق اين روايت حسن صباح براى مخفى ماندن راز اعمال و رفتار خود،

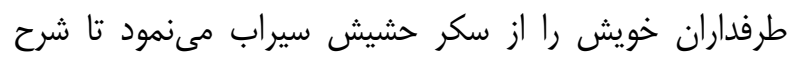
ماوقع اعمال ايشان هيجگاه در خاطر باقى نمانده و به بير بيرون
مصرف حشيش و الكل كه به صورت رسمى يا در نتيجه خود

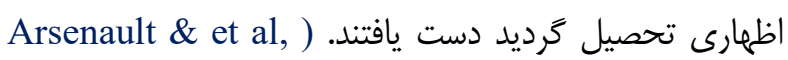
(2000: 979 حسب مطالب فوق، جرايم قابل ارتكاب توسط اين افراد به دو كروه قابل تقسيم است: نخست جرايم "مربوط بهه مواد مخدر

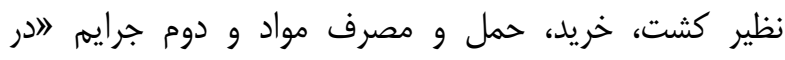

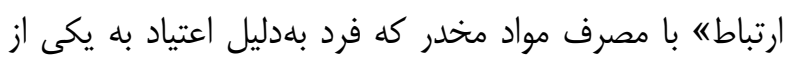
كونههاى مواد مخدر مرتكب برخى از انواع جرايم مى

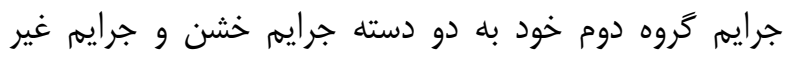
خشن قابل تقسيم است. غالب جرايم غير خشن كه توسط اين افراد ارتكاب مىيابد از جمله جرايم عليه اموال است هيه آنكه به عنوان مثال. بسيار شايع است كه فرد معتاد بهدليل تأمين

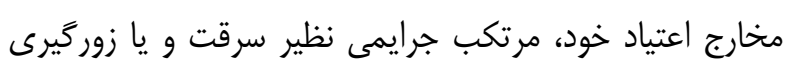

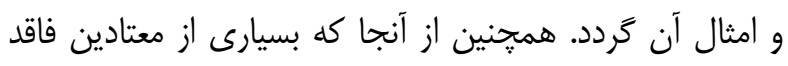
كسب و ييشه معينى هستند، سرقت در ميان اين گروه، نه تنها جهت تأمين هزينه اعتياد بلكه تأمين هزينههاى خوراك، دئه يوشاك و مسكن و ساير خدمات، بسيار مشاهده مىشود. تحقيقى كه توسط دو تن از محققين بنام آنجلين و بال صورت

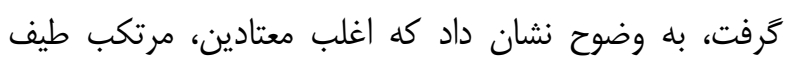
وسيعى از جرايم مىشوند. به زعم اين دو، هنكامى كه نياز به مصرف هروئين در ميان اين گروه افزايش مى يابد، به نسبت، نرخ جرايم نيز افزوده شده و بالعكس، در موارد كاهش تمايل به ميه مصرف، از نرخ بزهكارى مزبور نيز كاسته مى تشود. معتادين تحت مطالعه در باليتموى نيز بدليل اعتياد شديد به مركيه

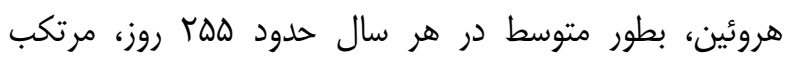

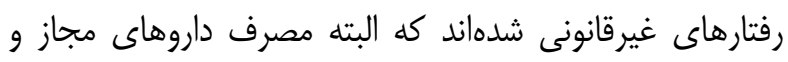
مواد مخدر نيز در اين آمار ملحوظ قرار كَرفته است. نرخ بزهكارى اين گروه در صورت فقدان مصرف شديد هروئين تنها ه9 روز در طول سال كزارش شده است. در مجموع، بلنظر مىرسد كه •^د درصد از جرايم مالى اين كروه به منظور تأمين

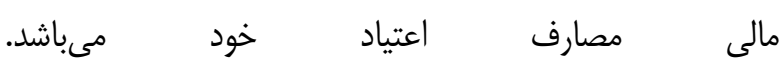
encyclopedia.com/Drug Legislation: For and )

(Against, 2018 
شخص خاصى استفاده نمايد، ايشان را در حالت خواب از بهشت بيرون آورده و وقتى كه بيدار مى شوند در نتيجه خمارى حاصل حاصل از از حضور در باغ كمان مىبرند كه كويى در حضور بيامبر اعظم شرفياب

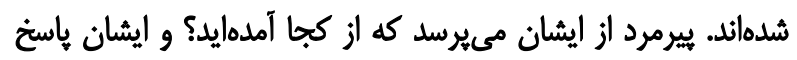
مىدهند: از بهشت. ساير جوانان كه هنوز وارد باغ نشدهاند با شنيدن

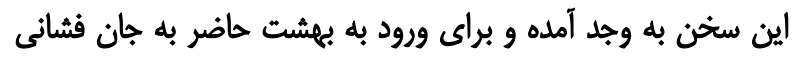
و انجام ماموريتهاى خطرناك در وقت معين مى مردند."

(Mandel, 1966: 149)

ه- افزايش مصرف مواد مخدر سخت (نظزيه دروازه ورود) برخى معتقدند كه مصرف حشيش موجب مصرف ساير انواع

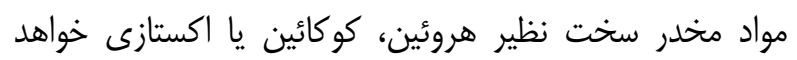
شد. (DuPond, 1984 : 20) به زعم اين كروه مصرف حشيش نقطه آغاز مصرف ساير مواد مخدر سخت و مجراى ورود به آن بلشمار مىآيد. ايشان در تائيد نظرات خود به مانه مطالعاتى استناد مىنمايند كه طبق آن، كسانى كه تجربه

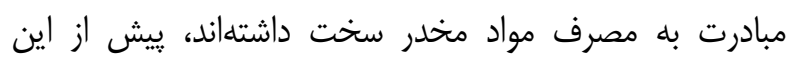
تجربه استفاده از حشيش را نيز داشتهاند. به اين نظريه، التئورى مورى دروازه وروده كفته مىشود. يعنى مصرف حشيش دروازه ورود مصرف ساير انواع مواد مخدر سخت است. در ايالات متحده، نخستين بار دكتر آنسلينكر در شهادت خود در

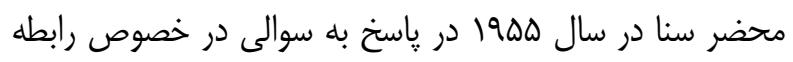
ميان مصرف حشيش و هروئين اذعان نمود: انكرانى عمده ما در

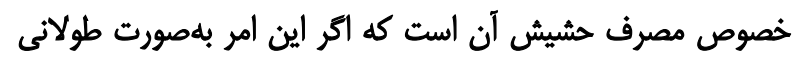
مدت صورت كيرد، منجر به اعتياد به هروئين خواهد شد.ه وى همجنين در سال •و19 بار ديخر در پاسخ به اين سوال كميته كه آيا مصرف حشيش موجب اعتياد به هروئين مى گردد اذعان داشت: "ابلى، مصرف حشيش به ويزه در ايالتهاى نيويورى و لسآنجلس، آغاز مسيرى است كه به هروئين ختم خواهد شد. معمولا همه جيز از مصرف حشيش آغاز مىشود و سيس مصرف لهان كنندكان با تغيير ذذائه خواستار امتحان كردن مادهاى قوىتر خواهند بود. در اين جا است كه تمايل به مصرف هروئين بوجود مى آيد و اين آغاز مشكلات است. (Hearing, 1960: 182)
درز ننمايد. (Wolf, 1936: 119) به هر حال اين دليل هنوز به عنوان توجيه رابطه ميان مصرف حشيش و ارتكاب خشونت مورد استفاده قرار مى گيرد. دكتر رونالد اوريا، رياست ييشين شوراى مشورتى اعتياد به مواد مخدر ايالت نيويورك، در همين رابطه مى گويد: لامكان بالقوه خشونت آميز بودن مصرف حشيش، در نفس اين كلمه و سابقه تاريخى آن نهفته است. جه آنكهاين كلمه مشتق از نام كسى است كه در قرن سيزده بعد از ميلاد از حشيش براى آماده كردن ياران خود جهت ارتكاب جرايم خشونتآميز استفاده مىنمود." علاوه بر اين دكتر ادوارد بلوم كوايست،

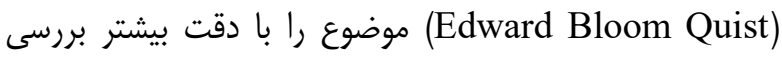
نموده است: لادر خصوص اينكه لفظ تروريست (Assassin) مشتق از كلمه حسن (Hassan) است يا حشيش (Hashish)

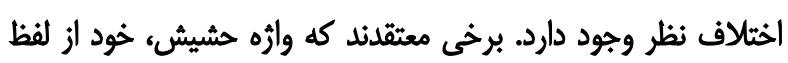
حسن ريشه كرفته است. با اين وجوده يك جيز قطعى است و آن آن اينكه مفاهيم حسن، حشيش و ترور، در ارتباط با فدائيان قلعه الموت با يكديكر بيوند خوردهاند. و حكايت از ارتكاب رفتارهاى خشونتآميز در نتيجه كسيختكى روحى ناشى از مصرف حشيش دارنده (Bloom, 1968: 27) در سالهاى اخير دو مطالعه عميق در خصوص ريشه اين كلمه صورت كرفته است. در نخستين يزوهش كَته شده كه ارتباط ميان دو كلمه Assassin و حشيش به احتمال زياد نشات كرفته از سفرنامه ماركويولو است: لادر درهاى ميان دو كوه، بزركترين و زيباترين باغى كه در عمرم مشاهده كردم وجود دارد. در اين باغ بهترين ميوههاى جهان، فراخترين خانهها و زيباترين اماكن موجود است كه مزين به تصاوير زيبايى از بهترين مناظر جهان

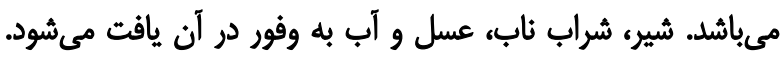
در اين باغ زنان و دوشيزكانى حضور دارند كه در زيبايى بىنظير بوده

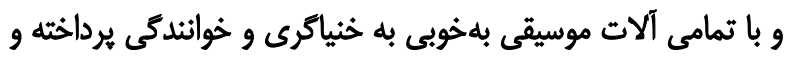
بهتر از هر زنى مىرقصند. در اين باغ هيج مردى با نخواهد كذاشت

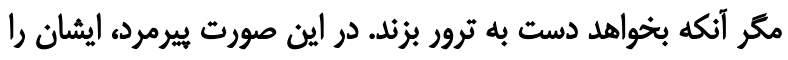

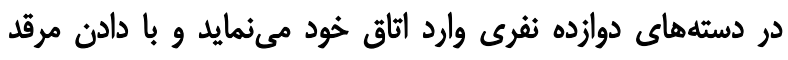

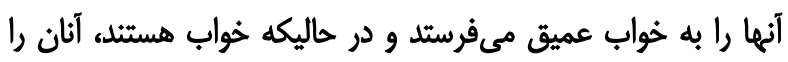
وارد باغ مىنمايد. هنكاميكه از خواب برخيزند، كويى كه واقعاً در

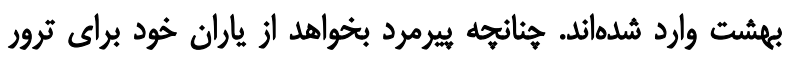


مؤسسأه مزبور با آزمايش بر روى سلولهاى مغز موشها دريافت كه مصرف حشيش با تأثير بر سيستم مرتبط با

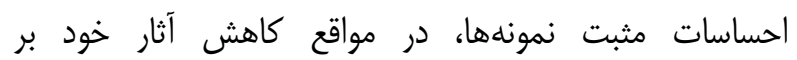
سلولهاى مغز، موجبات افزايش تمايل به مصرف بيشتر هروئين را ايجاد مىنمايد. (Vince, 2006: همجنين ون اورز (Van Ours) در مطالعات خود به شواهدى دست يافته كه نتيجه ذيل را براى وى به اورله همراه داشته است: "ادر هلند بسيارى از مصرف كنندكان حشيش از آسيبذيذيرى در لئه

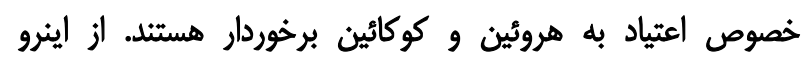

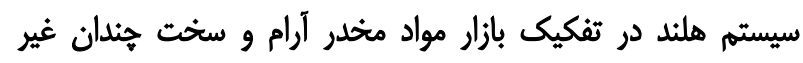
معقول نيست. از تحقيقات انجام كرفته مىتوان جنين استنباط نمود كه تجويز استفاده كنترل شده از مواد مخدر آرام داراى آثار تعيين

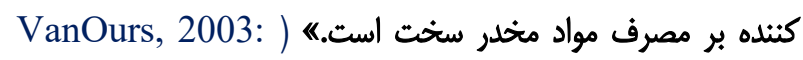

از مجموع تحقيقات و آزمايشات مذكور مىتوان بر درستى نظريه 》دروازه ورود" صحه كذارد.

\section{צ- نقض معاهدات بينالملى}

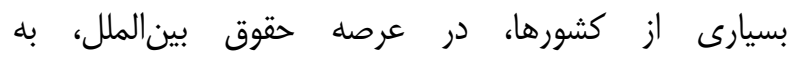

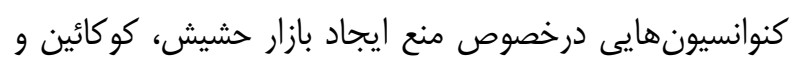

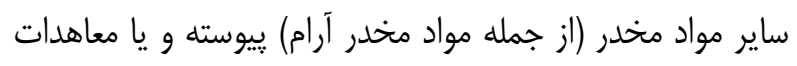
بسيارى در اين خصوص با ساير كشورها منعقد نمودهاند. به عنوان مثال آمريكا، كنوانسيون مواد مخدر و كنوانسيون مواد روان كردان را به امضاء رسانده و در راستاى كنترل و مجازاتِ توليد، قاجاق و مصرف آنها با ساير كشورها موافقتنامههايى ران امضاء كرده است. تاكنون حدود بالاكشور جهان از جمله ايران

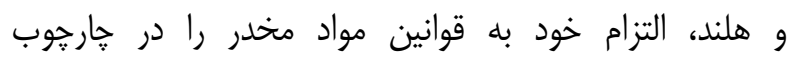
كنوانسيونها اعلام نمودهاند. با جنين توصيفى جِّونه مىتوان به جرمزدايى برخى از انواع مواد مخدر يرداخت؟ از منظر سير تاريخى، نخستين تلاش جهانى براى ممنوعيت حشيش در سطح بينالملل با اجتماع rا نماينده كشورهاى مختلف در شانكَماى جين آغاز شد. هدف كنفرانس 19.9 شانكماى بحث در خصوص امكان تهييه معاهدهاى جهت كنترل مواد مخدر با تمركز اصلى بر محدوديت واردات ترياك به كشور گين بود. دومين نشست در سال 19/1 در لاهه منتهى به
يكى از مشهورترين حاميان نظريه لحشيش؛ دروازه مصرف مواد مخدر سخته روبرت دويونت (Robert Dupont) رئيس سابق لميق مؤسسه ملى مبارزه با سوء مصرف مواد مخدر آمريكا است. وى سى دون در كتاب خود بنام اراهنماى خانواده ها در خصوص دروازه مصرف مواد مخدر سخته، تئورى مزبور را مورد تشريح قرار

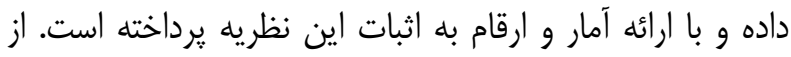
ديخر طرفداران اين تئورى آقاى دنيز كندل (Denise Kandel) مؤلف كتاب التئورى مدخليت حشيش براى مصرف مواد مخدر سخت 《 است. در سال همو1، كابريل جى ناهاس (Gabriel G.Nahas) كتابى را تحت عنوان 》از حشيش دورى نماييمه منتشر نمود و در آن خاطر نشان ساخت كه تغييرات حاصل از مصرف حشيش در مغز

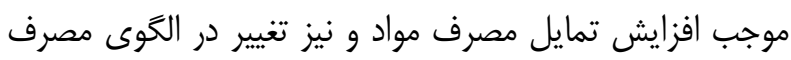
خواهد شد به نحوى كه بسيارى از استعمال كنندكان حشيش يس از مدتى به مصرف ساير انواع مواد مخدر سخت روى خواهند آورد. از اين رو خطر اعتياد به مصرف كو كائين و هروئين در نتيجه مصرف حشيش به خوبى روشن است. (Nahas,

(1985: 18

در سال 1990 》انجمن حمايت از امريكاى عارى از مواد مخدر" با حمايت موسسه ملى مبارزه با سوء مصرف مواد مخدر و دفتر

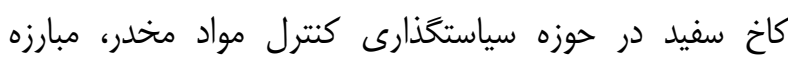

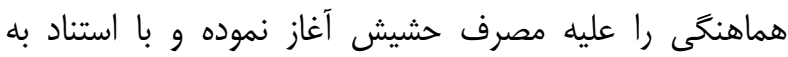
كزارش مركز مبارزه با اعتياد و سوء مصرف مواد مخدر ادعا نمودند كه مصرف كنندكان حشيش هم برابر بيش از سايرين در معرض اعتياد به كوكائين قرار دارند.

(Drcnet.org, 1960) در سال צ..r مؤسسه كاروليزكا (Karolinska) در سوئد به بررسى تأثير مصرف ساير انواع مواد مخدر سخت بر روى كأبل

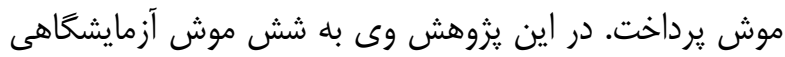

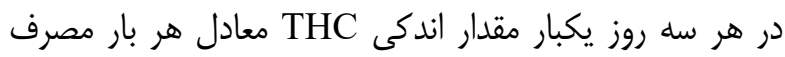
حشيش توسط انسان داد. اين نمونهها از امكان استفاده از هروئين نيز برخوردار بودند. آزمايشات نشان داد كه تمايل نمونهاى مزبور به استفاده از هروئين افزايش يافته است. 
همجنين طبق اين كنوانسيون توزيع، فروش و حتى توليد

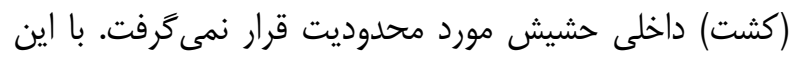
وجود برخى از كشورها نظير ايالات متحده با اتخاذ سياست كيفرى اقتداركرا و خشن، حتى موارد غيرمصرّح دركنوانسيون را نيز مورد جرم انخارى قرار دادند. ) Marcel, 1994:3; Leuw

(\& Marshal, 1994: 113; Fromberg, 1994: 124 اين شرايط در سال اعو19 با تصويب كنوانسيون واحد كه تحت مديريت سازمان ملل و با هدف تجميع تمامى معاهدات و و

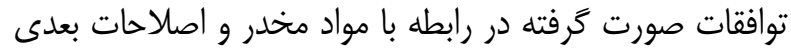
آن تصويب شد كاملاً تغيير يافت. با اين حال كنوانسيون مزبور در شكل نهايى خود بسيار جلوتر از توافقات قبلى حركت كرد و محدوديتهاى جديدى را نيز به كشورهاى عضو تحميل نمود. بر اساس اين كنوانسيون، حتى توليد (كشت) داخلى حشيش جز به منظور اهداف علمى و درمانى ممنوع گَرديد. همجنين حمل حشيش نيز جرمى مستحق كيفر به شمار آمد و كشورهاى عضو ملزم شدند كه اتدابير اجرايى و تقيينى مشابه" را جهت مبارزه با مصرف و قاجاق حشيش اتخاذ نمايند. بلطور خاص،

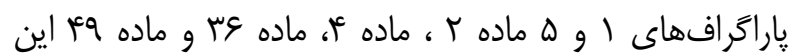
كنوانسيون ناظر بر محدوديتهاى حقوقى مزبور است.

(Norml.com, 2015) ماده r ז يروتكل اصلاحى كنوانسيون واحد سازمان ملل در 1971 با انعكاس مفاد كنوانسيون 1991 مقرر مىدارد كه هر يك از اعضاء، ملزم به مجازات نمودن رفتارهاى عامدانه مغاير با مفاد اين كنوانسيون مىباشند و از آنجا كه تركيبات حشيش و

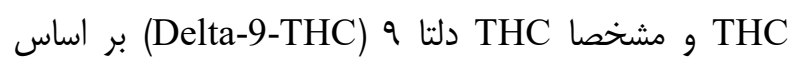
جدول اول و دوم ييوست اين كنوانسيون جزء مواد روان گردان تلقى شدهاند، از اينرو جرمانگارى مصرف حشيش توسط دول امضاءكننده اين كنوانسيون اجتناب نايذير خواهد بود. همجنين كنوانسيون سازمان ملل متحد براى مبارزه با مواد

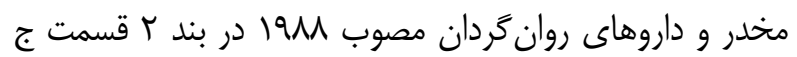

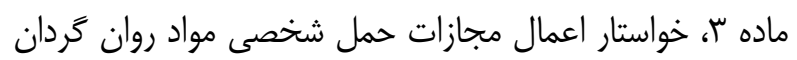
توسط افراد شده است. طبق اين بند: ال..... هر يك از اعضاء
اضافه شدن ماده مخدر كوكائين به فهرست مواد مخدر تحت

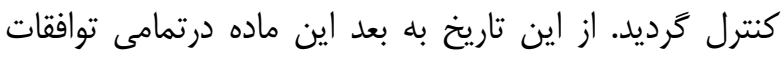
بينالملى به عنوان ماده مخدر به شمار آمد. با اصرار ايالات متحده و ايتاليا، مسأله حشيش نيز در دستور كار قرار ترفت اما مباحث مطرح شده در رابطه با آن مختصر و كذرا بوده و نهايتاً به عنوان ماده مخدر تحت كنترل معرفى نغرديد. در كنفرانس بعدى كه در زنو بركزار كَرديد اعضاء جامعه ملل توافق نمودند

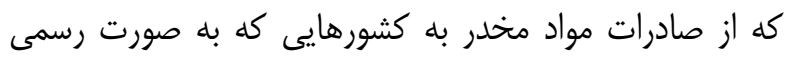
واردات مواد مخدر جز جهت مصارف درمانى و اهداف علمى را ممنوع نمودهاند اجتناب نمايند. در اين كنفرانس ايالات متحده ييشنهاد كرد كه حشيش نيز به فهرست مواد مخدر تحت كنترل اضافه گردد. در آن زمان بسيارى از كشورهاى حاضر در در برد كنفرانس در سطوح ملى مشكل خاصى در خصوص شيوع اين

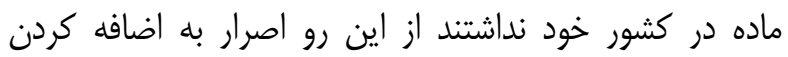
حشيش نمىتوانست مقاومت خاصى را توسط اين كشورها بر انغيزاند. علاوه بر آن مصر، آفريقا و كانادا نيز كزارشاتى را در خصوص مشكلات ناشى از مصرف اين ماده در كشور خود ارائه

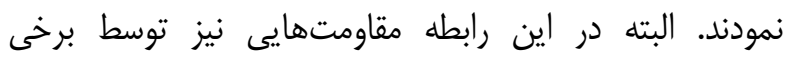
كشورهاى صادر كننده مواد مخدر (كه تجارت بينالمللى ايشان بدين نحو مورد تهديد قرار گرفته بود) صورت يذيرفت اما هيج كدام از كشورهاى تأثير كذار حاضر در اين كنفرانس، بدليل فقدان منافع مالى مخالفتى با اين موضوع نشان ندادند. يس از اين كنفرانس كشورهايى كه تاكنون اقدامى در اين زمينه انجام

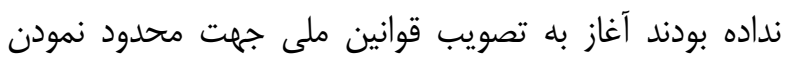
واردات حشيش كردند. در واقع از آنجا كه كنفرانس زنه كشورهاى صادر كننده مواد مخدر را ملزم به محدود نمودن

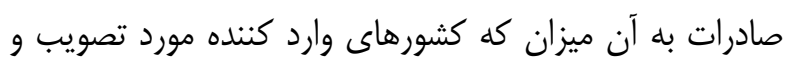
تأييد قرار مى دهند نموده بود، از اينرو تصويب قوانين داخلى در كشورهاى وارد كننده، جهت تعيين مقدار حشيش قابل صادرات توسط دول صادر كننده اجتناب نايذير مىنمود. البته كنوانسيون مزبور به هيج وجه حمل و يا مصرف حشيش در ميان شهروندان دول عضو را مورد اشاره و منع قرار نداده بود. 
رابطه از ديگر موانع حقوقى در سر راه اجراى سياست جرمزدايى مواد مخدر به شمار مى آيد. V- ل هاك كردن صورت مساله تاكنون تلاشهاى بسيارى جهت كنترل مواد مخدر در تمامى مورت مهاه كشورهاى دنيا اعم از دولتهاى دينى و سكولار صورت كَرفته است و هزينههاى بسيارى در اين خصوص صرف شده و البته

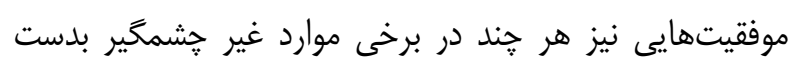

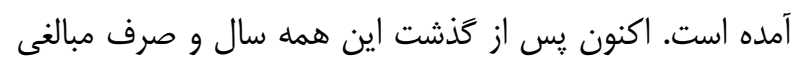
هنحَفت در اين مسير و كسب تجارب ارزنده در اين راه، سخن كفتن از جرمزدايى و ترى تعقيب كيفرى و كنترل بازار توليد و توزيع و مصرف مواد مخدر امرى سقيم خواهد بود. آنجه كه جامعه طالب آن بوده برداشتن گامهايى استوار در اين مسير

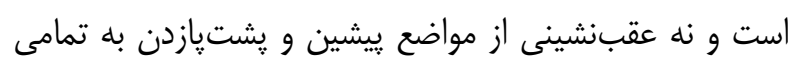

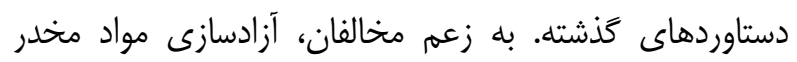

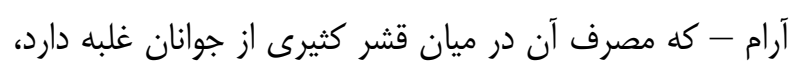
در واقع دست كشيدن از مواضع قانونى و تسليم شدن به شرايط و مقتضيات كنونى است. به عبارت ديخر، اين امر به معناى شكست سياستهاى مبارزه با مواد مخدر و سازش بات با اميال

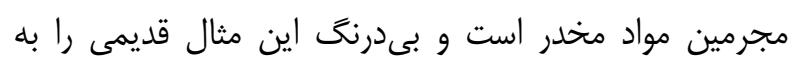
ذهن مى آورد كه ا|كر توان مقابله با كسى را ندارى با وى مصالحهد

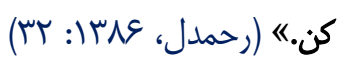

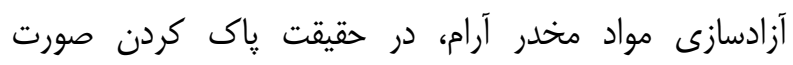

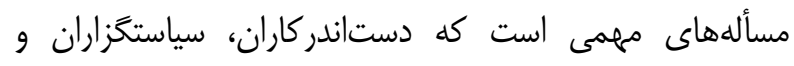
كارگزارن دولتى به دليل عدم كفايت، قادر به حل كلاف سردرّم آن نبودهاند. جرمزدايى، نوعى شانه خالى كردن از بار

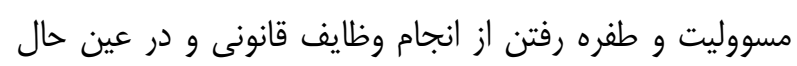
مدرن جلوه دادن ديدكاهها و انديشههاى خود است.

\section{نتيجه}

جرمزدايى از مصرف مواد مخدر آرام مانند حشيش و تلاش براى قانونمند كردن مصرف آن، آرجهه ممكن است واجد فوائد و آثار مثبت نيز باشد ليكن در تعارض با بسيارى از قواعد

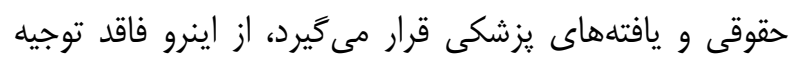

كنوانسيون تدابير لازم را به منظور جرم قلمداد كردن عمل حمل،

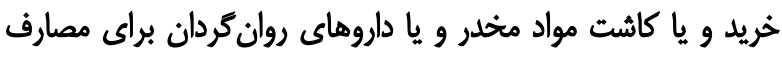

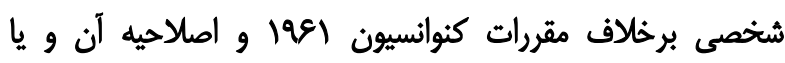

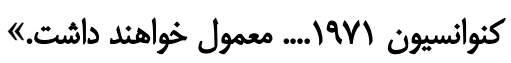
از اين تاريخ به بعد مىتوان طيف متنوعى از سياستهاى

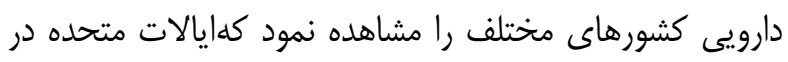

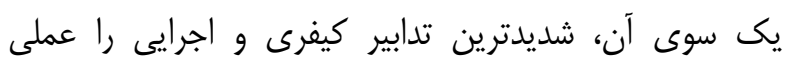

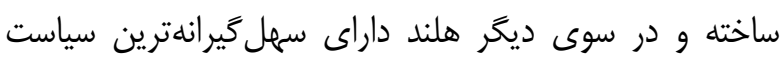

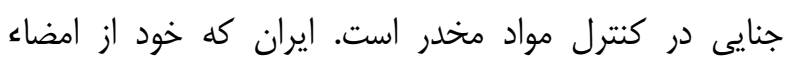

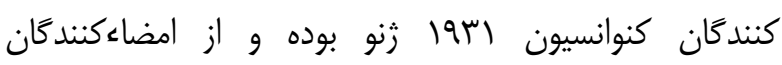

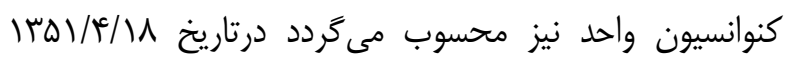

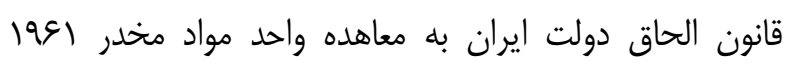

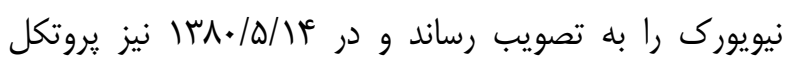

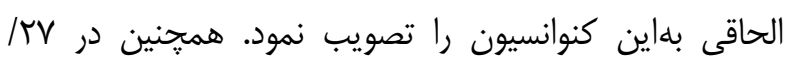

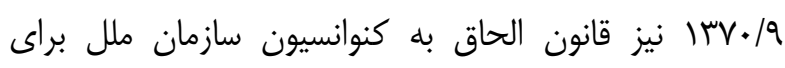

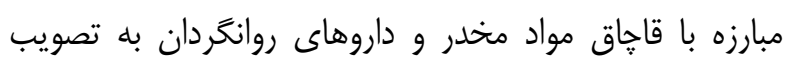

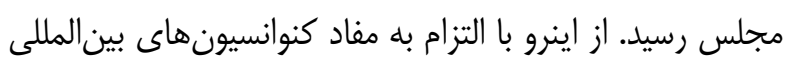

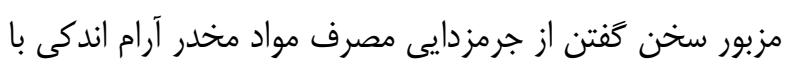
دشوارى رو برو است. علاوه بر كنوانسيونهاى مذكور كه دول ايران، هلند و ايالات متحده جملكى به تصويب آن يرداخته اند، دولت هلند در سال

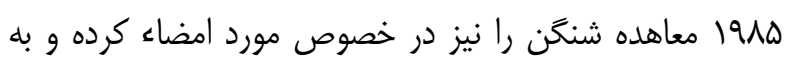
كنوانسيون •199 نيز بيوسته است. ماده ل V كنوانسيون اخير

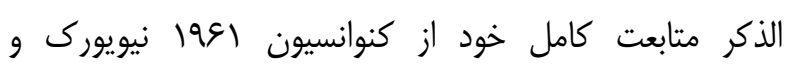

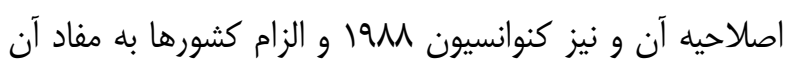
را مورد تاكيد قرار داده است. همرنين كنوانسيون شوراى ارويا در خصوص قاجاق مواد مخدر از طريق دريا، دول عضو را از

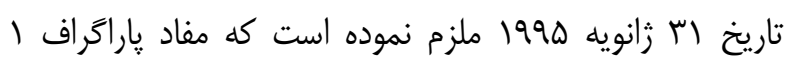
ماده ب كنوانسيون 19MM سازمان ملل را در سيه سياهه عناوين كيفرى داخلى خود وارد نمايند. رهنمود شوراى ارويا در خصوص

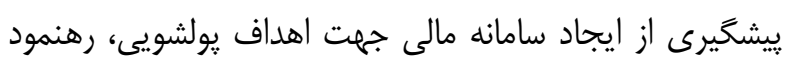

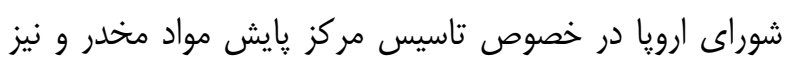
توافقات دو جانبه هلند با ساير كشور ها نظير ونزوئلا در اين 
تشكر و قدردانى: از تمامى كسانى كه در حوزه يزوهشهاى مواد مخدر ما را در تهيه اين مقاله يارى رساندهاند، سياسخَزاريم.

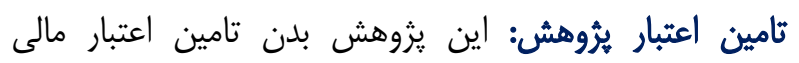

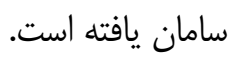

ملاحظات اخلاقى: موارد مربوط به اخلاق در يزوهش و نيز امانتدارى در استناد به متون و ارجاعات مقالهات مردات تماماً رعايت كرديد. تعارض منافع: تدوين اين مقاله، فاقد هرگَونه تعارض منافعى بوده است. سهم نويسندكان: نغارش اوليه مقاله توسط نويسنده مسوول

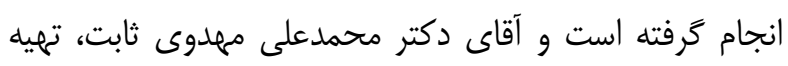
منابع، ترجمه متون و نغارش نهايى را عهدهدار بودهاند 
•ه/ فصلنامه بزُوهشهاى حقوقى ميانرشتهاى، دوره اول، شماره اول، بهار و9"ا

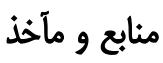




$$
\begin{aligned}
& \text { الف. منابع فارسى - (حسان } \\
& \text { - احسانيور، سيدرضا و احسانيور، سيدمحمدرضا (هوساب). } \\
& \text { "توجيهات جرمزدايى از مصرف مواد مخدر آرام". فصلنامه }
\end{aligned}
$$

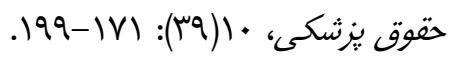

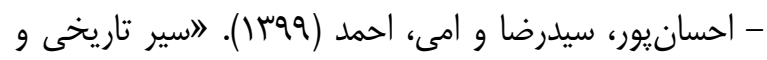

$$
\begin{aligned}
& \text { تحولات جرمزدايى از مصرف مواد مخدر آرامها. فصلنامه }
\end{aligned}
$$

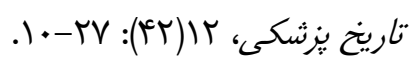

$$
\begin{aligned}
& \text { - احسانيور، سيدرضا؛ رضايى، راحله و الدبداشتى، ندا }
\end{aligned}
$$

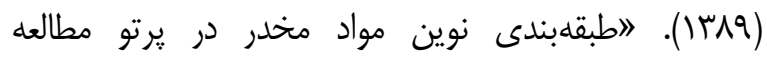

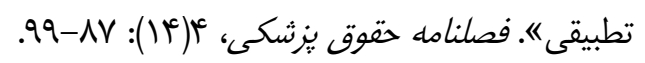

$$
\begin{aligned}
& \text { - اردبيلى، محمدعلى (Vوسا). حقوق جزاى عمومى. جلد اول، } \\
& \text { حاب هفدهم، تهران: انتشارات ميزان. }
\end{aligned}
$$

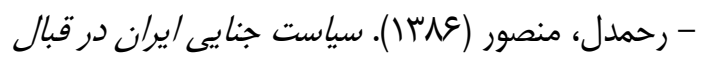

$$
\begin{aligned}
& \text { جرايمر مواد مخدر. تهران: انتشارات سمت. }
\end{aligned}
$$

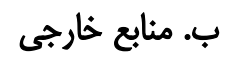

- Anslinger, H (1937)."Assassin of Youth". The American magazine, 124:156-169

- Arseneault, L; Moffitt, T; Caspi, A; Taylor, P \& Silva, P (2000). "Mental Disorders and Violence in Total Birth Cohort: Results From The Dunedin Study". Archives of General Psychiatry, 57(2): 979-986.

- Bloom quist, E (1968). Marijuana. USA: Glencoe Press. via:www.mmp.org (Last revised: 2020)

- Brook, J; Balka, E. \& Whiteman, M (1999). "The Risks For Late Adolescence of Early Adolescent Marijuana Use". American Journal of Public Health, 89(3): 1549-1554.

- Donovan, J. \& Jessor, R (1983). "Problem Drinking And The Dimension of Involvement With Drugs: A Guttman Scalogram Analysis of Adolescent Drug Use. American Journal of Public Health, 73(2): 543-552.

- DuPont, R (1984). Getting Tough on Gateway Drugs.Washington, DC: American Psychiatric Press.

- Fergusson, D. \& Horwood, L (1997). "Early Onset Cannabis Use And Psychosocial Adjustment In Young Adults". Addiction, 92(2): 279-296.

- Fromberg, E(1994). The Case of the Netherlands: Contradictions and Values. International Antiprohibition League.

- Fussier, A (1931). "The Marijuana Menace”. New Orleans medical \& surgical journal, 25(2): 84-95.

- Hearings, H (1960). "Hearings before the Subcommittee of the Committee on Appropriations". House of Representatives, 25(3): 182.

- Johnston, L ; O’Maley, P \& Eveland, L (1978). Drugs and delinquency: Asearch for causal connections. New York: John Wiley and Sons.

- Kaplin, S (1994). The Effects Of Harm Reduction $V$. Harm Prevention: An International Assessment. Via: www.NORML.com (last revised: 2020)

- Kleiman, M (1992). Against Excess: Drug Policy for Results. New York: Basic Books Press.

- Leuw, E and Marshal, I.H (1994). Between Prohibition and Legislation: The Dutch Expriment in Drug Policy, Amesterdam: Kugler Publications.

- Mandel, j(1966). Hashish, Assassin and The Love Of God. Vol 2, Usa: Issues in Criminology. 
- Marcel D (1994). A short History of Drugs in the Netherlands via: www.NORML.com (last revised: 2020)

- Marijuana's Gateway Myth via: http://www.drcnet.org (Last Revised: 2020)

- Nahas, G (1985). Keep off the Grass. via: www.mmp.org (Last Revised: 2020)

- Newcomb, M \& Bentler, P (1988). Consequences of adolescent drug use. California:, Sage Publications.

- Polich, J; Ellickson, P; Reuter, P \& Kahan, J (1984). Strategies for Controlling Adolescent Drug Use. CA: The RAND Corporation.

- Reuter, P \& Kleiman, M (1986). Risks And Prices: An Economic Analysis Of Drug EnforcementVol. 7, Chicago: University of Chicago Press.

- Salmelainen, P (1995). The Correlates of Offending Frequency: A Study of Juvenile Theft Offenders In Detention. Sydney: New South Wales Bureau of Crime Statistics and Research.

- Trimboli, L (1998). “Cannabis and Crime: Treatment Pprograms for Adolescent Cannabis Use". Crime and Justice Bulletin, 41(2): 1-16.

- Van Ours, J (2003). "Is Cannabis A SteppingStone For Cocaine?" Journal of Health Economics, 22(2): 539-554.

- Vince, G (2006). "Why Teenagers Should Steer Clear of Cannabis" via: http://www.newscientist.com/article. (Last revised: 2020)

- Warner, K (1991). “Legalizing Drugs: Lessons From (And About) Economics". Milbank Quarterly, 69(3): 641-661.
- White, H (1991). "Marijuana Use and Delinquency: A Test of the 'Independent Ccause' Hypothesis." Journal of Drug Issues, 21(3): 231-256.

- Wolf, W ( 1936). "Uncle Sam Fights New Drug Menace: Marijuana." Popular Science Monthly, 12 (2):119-132.

- Zimmer, L (2018). The History of Canabis Prohibition: via: www.NORML.com (Last Revised: 2020)

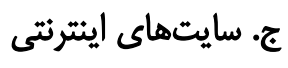

- www.drcnet.org (Last Revised: 2020)

- www.Freedictionary.com (Last Revised: 2020)

- www.mmp.org (Last Revised: 2020)

- www.newscientist.com (Last revised: 2020)

- www.NORML.com (Last Revised: 2020)

- www.OxpordDictionary.con (Last Revised: 2020) 


\section{References}

- Anslinger, H (1937)."Assassin of Youth". The American magazine, 124:156-169

- Ardebili, MA (2019). General Criminal Law. Vol $1,17^{\text {th }}$ ed. Tehran: Mizan Press. (Persian)

- Arseneault, L; Moffitt, T; Caspi, A; Taylor, P \& Silva, P (2000). "Mental Disorders and Violence in Total Birth Cohort: Results From The Dunedin Study". Archives of General Psychiatry, 57(2): 979-986.

- Bloom quist, E (1968). Marijuana. USA: Glencoe Press. via:www.mmp.org (Last revised: 2020)

- Brook, J; Balka, E. \& Whiteman, M (1999). "The Risks For Late Adolescence of Early Adolescent Marijuana Use". American Journal of Public Health, 89(3): 1549-1554.

- Donovan, J. \& Jessor, R (1983). "Problem Drinking And The Dimension of Involvement With Drugs: A Guttman Scalogram Analysis of Adolescent Drug Use. American Journal of Public Health, 73(2): 543-552.

- DuPont, R (1984). Getting Tough on Gateway Drugs.Washington, DC: American Psychiatric Press.

- Ehsanpour, SR \& Ehsanpour, SMR (2016). "Justifications For Decriminalization of Soft Drugs". Journal of Medical Law, 10(39): 171199. (Persian)

- Ehsanpour, SR \& Ommi, A (2020). "Timeline of Decriminalization of Soft Drugs". Journal of Medical History, 12(42): 10-27. (Persian)

- Ehsanpour, SR; Rezai, R \& Bedashti, N (2010). "Comparative Study on Classification of Drugs". Journal of Medical Law, 4(14): 8799. (Persian)
- Fergusson, D. \& Horwood, L (1997). "Early Onset Cannabis Use And Psychosocial Adjustment In Young Adults". Addiction, 92(2): 279-296.

- Fromberg, E(1994). The Case of the Netherlands: Contradictions and Values. International Antiprohibition League.

- Fussier, A (1931). "The Marijuana Menace”. New Orleans medical \& surgical journal, 25(2): 84-95.

- Hearings, H (1960). "Hearings before the Subcommittee of the Committee on Appropriations". House of Representatives, 25(3): 182.

- Johnston, L ; O’Maley, P \& Eveland, L (1978). Drugs and delinquency: Asearch for causal connections. New York: John Wiley and Sons.

- Kaplin, S (1994). The Effects Of Harm Reduction $V$. Harm Prevention: An International Assessment. Via: www.NORML.com (last revised: 2020)

- Kleiman, M (1992). Against Excess: Drug Policy for Results. New York: Basic Books Press.

- Leuw, E and Marshal, I.H (1994). Between Prohibition and Legislation: The Dutch Expriment in Drug Policy, Amesterdam: Kugler Publications.

- Mandel, J (1966). Hashish, Assassin and The Love Of God. Vol 2, Usa: Issues in Criminology.

- Marcel, D (1994). A short History of Drugs in the Netherlands via: www.NORML.com (last revised: 2020) 


\section{- Marijuana's Gateway Myth via:} http://www.drcnet.org (Last Revised: 2020)

- Nahas, G (1985). Keep off the Grass. via: www.mmp.org (Last Revised: 2020)

- Newcomb, M \& Bentler, P (1988). Consequences of adolescent drug use. California:, Sage Publications.

- Polich, J; Ellickson, P; Reuter, P \& Kahan, J (1984). Strategies for Controlling Adolescent Drug Use. CA: The RAND Corporation.

- Rahmdel, M (2007). Iranian Criminal Policy Towards Drugs. Tehran: Mizan Press. (Persian)

- Reuter, P \& Kleiman, M (1986). Risks And Prices: An Economic Analysis Of Drug EnforcementVol. 7, Chicago: University of Chicago Press.

- Salmelainen, P (1995). The Correlates of Offending Frequency: A Study of Juvenile Theft Offenders In Detention. Sydney: New South Wales Bureau of Crime Statistics and Research.

- Trimboli, L (1998). “Cannabis and Crime: Treatment Pprograms for Adolescent Cannabis Use". Crime and Justice Bulletin, 41(2): 1-16.

- Van Ours, J (2003). "Is Cannabis A SteppingStone For Cocaine?" Journal of Health Economics, 22(2): 539-554.
- Vince, G (2006). "Why Teenagers Should Steer Clear of Cannabis" via: http://www.newscientist.com/article. (Last revised: 2020)

- Warner, K (1991). "Legalizing Drugs: Lessons From (And About) Economics". Milbank Quarterly, 69(3): 641-661.

- White, H (1991). "Marijuana Use and Delinquency: A Test of the 'Independent Ccause' Hypothesis.” Journal of Drug Issues, 21(3): 231-256.

- Wolf, W ( 1936). "Uncle Sam Fights New Drug Menace: Marijuana." Popular Science Monthly, 12 (2):119-132.

- www.drcnet.org (Last Revised: 2020)

- www.Freedictionary.com (Last Revised: 2020)

- www.mmp.org (Last Revised: 2020)

- www.newscientist.com (Last revised: 2020)

- www.NORML.com (Last Revised: 2020)

- www.OxpordDictionary.con (Last Revised: 2020)

- Zimmer, L (2018). The History of Canabis Prohibition: via: www.NORML.com (Last Revised: 2020) 